\section{BDA BULLETIN}

- After a successful appeal raised $€ 60,000$, the painting The Dentist has been purchased by the BDA Museum. Painted in 1929 by Sir John Lavery, the portrait features dentist Conrad Ackner in situ treating his patient, the artist's wife, Lady Lavery. The work is the only known accurate depiction of the early twentieth century dentist in a surgery and will go on permanent display in the BDA Museum.

- Dentists from across the UK are invited to nominate themselves for membership of 13 BDA committees that represent practitioners working in general practice (including wholly private practice), salaried primary care, hospital services, academia and the armed forces. BDA members and non-members alike are eligible for membership of the committees. Email gettinginvolved@bda.org for a nomination pack. Packs must be returned by $5 \mathrm{pm}$ on Friday 140 ctober. Dentists elected to the committees will serve a three-year term beginning early in 2012.

- The BDA has written to Dentistry Minister Earl Howe to demand an urgent meeting to make progress on a Department of Health decision to withdraw Seniority Pay for general dental practitioners in England reaching the age of 55 after 1 April 2011. The letter sets out the profession's frustration and anger at an apparent lack of progress on, or communication about, the proposals. It also calls on the Minister to reinstate the scheme until an alternative is developed.

\title{
NEW CHAIR FOR GENERAL DENTAL COUNCIL
}

The General Dental Council (GDC) has announced that Kevin O'Brien has been elected Chair of the GDC with immediate effect.

Professor 0'Brien assumes the role in a permanent capacity, replacing Derek Prentice who was elected Deputy Chair earlier this year.

'I look forward to leading this experienced and talented Council in public protection - our key role,' said Professor 0'Brien, who was born in Edinburgh and is now based in Manchester Dental School where he is Professor of Orthodontics. He has previously worked with the GDC in the roles of Chair of the Specialist Dental Education Board, as a member of the strategic review of undergraduate training and as Chair of the Education Committee.

\section{DIARY}

\section{OCTOBER}

BDTA Dental Showcase
Date: 20-22 October 2011
Venue: NEC, Birmingham
www.dentalshowcase.com
Bruxism Awareness Week 2011
Date: 24-30 October 2011
Tel: 01142500176
(for free information pack)
Email: info@s4sdental.com
www.s4sdental.com

\section{NOVEMBER}

BACD 'Something to Smile

About' conference

Date: 11-12 November 2011

Venue: Hilton London Metropole Hotel

Tel: 02082418526

Email:suzy@bacd.com
Dental Protection Premier Symposium 2011 Date: 26 November 2011 Venue: Imperial College, London Tel: 02073992914

Email: events@dentalprotection.org

\section{DECEMBER}

FGDP(UK) Third National Dental Care Professionals Research Day

Date: 3 December 2011

Venue: Royal College of Surgeons of England Tel: 02078696750

Email:anarain@rcseng.ac.uk

DentEd IRMER Update with Law \& Ethics Date: 8 December 2011

Venue: London Barbican Thistle Hotel

Tel: 08456532147

www.dent-ed.com

AOG 30th anniversary Annual Ball

Date: 10 December 2011

Venue: Millennium Hotel London www.aoguk.org 